\title{
Ameliorative effects of flaxseed and soybean oils on male rat fertility
}

\author{
Sally Mohsen, Shimaa El-Sayed, Mohammed El-Adl, Mohammed Fouda and El-Said El-Sherbini
}

Department of Biochemistry and Chemistry of Nutrition, Faculty of Veterinary Medicine, Mansoura University

ABSTRACT

\begin{abstract}
This study was designed to determine the effect of polyunsaturated fatty acids (PUFAs) present in flaxseed oil and soybean oil on fertility of male rats. Twenty-four male rats were divided into four groups each group contain six rats. The first group, the control group, received oil-free diet. The second group received diet contains flaxseed oil, the third group received diet contains soybean oil and the fourth group received diet contains both flaxseed oil and soybean oil with the ratio of $75 \%: 25 \%$, respectively. Serum samples were collected for reproductive hormones analysis (LH, FSH and testosterone). Testicular tissues were collected with the head of epididymis for sperm cell count and semen quality test. Testicular tissues specimens were taken for histopathological examination, 17ß-HSD3 gene expression and enzymatic activity as well as estimation of the antioxidant activity. The results of serum hormonal analysis showed a significant increase in testosterone and FSH levels without elevation in LH level. There was a significant increase in sperm cell count and semen quality in all three oil supplemented groups. Similar results were observed in gene expression analysis and enzyme activity of $17 \beta$-HSD3. Malondialdehyde (MDA) level was lower in all oil groups especially soybean oil group without significant differences between the four groups in nitric oxide (NO) level. Reduced glutathione (GSH) level was higher in oil groups than the control one. Glutathione $\mathrm{S}$ transferase (GST) activity was higher in group received both soybean and flaxseed oils without significant differences between the other groups including the control group. Finally, flaxseed and soybean oils have positive effects on spermatogenesis and steroidogenesis.
\end{abstract}

Keywords: Flaxseed, Soybean, $17 \beta-H S D 3$, MDA

\section{INTRODUCTION}

Nutritional habits are important factors affecting male fertility. Fats present in diet (Esmaeili et al., 2014), micro minerals (Prasad, 2013) and vitamins (Vujkovic et al., 2009) may have positive effects on semen quality especially PUFAs. Different dietary resources of fats and oils and their effect on the biology of spermatozoa become of a great interest (Wathes et al., 2007). Consumption of nutrients, insufficient to the body needs, can resulted in negative effects to spermatogenesis and normal spermatozoal morphology (Mosher and pratt, 1991 ). Mammals lack enzymes suitable for desaturation of fatty acids (FAs), so $n-6$ or $n-3$ unsaturated fatty acids can't be synthesized by de-novo pathway. So that, diet must contain both long chain fatty acids such as LA (C18:2 $n-6)$ and ALA (C18:3 n-3) as they are very essential for brain, vision and reproductive system (Kochhar, 2002).

Steroidogenic process is stimulated by gonadotropin (GnRH) secreted from the hypothalamus and stimulates LH secretion from the adenohypophysis. LH binds to receptors present on leydig cells surface and stimulates testosterone production from cholesterol through enzymes dependent pathway (Payne and Youngblood, 1995). There are over fourteen isoforms of $17 \beta$ HSD (Penning, 1997) but only type3 present in leydig cell is necessary for testosterone formation from androstenedione (Ge and Hardy, 1998). 17ß hydroxysteroid dehydrogenase enzyme requires NADPH as a cofactor and its mutation result in different phenotypes as pseudo-hermaphroditism with much lower circulating testosterone level in males (Anderson et al., 1996 and Rosler et al., 1996).

Oxidative stress is generated from oxidation and peroxidation of cellular components including DNA, carbohydrate, lipids and proteins (Pryor, 2006). Oxidative stress-induced by thermal stress can resulted in damage to DNA and testicular cell apoptosis (Aktas et al., 2012). Endogenously reactive oxygen species (ROS) induces damages causing various diseases including infertility (Gagnon et al., 1991). Natural anti-oxidant nutrients have the ability to preserve spermatozoa from oxidative stress and enhance fertility of male (Jedlinska- Krakowska et al., 2006).

Flaxseed oil has lower saturated fatty acid (SFAs) (9\%), moderate mono-unsaturated fatty acids (MUFAs) $(18 \%)$ and higher PUFAs (73\%) nearly about 55\%ALA (Thomas, 2002). Soybean oil is very popular polyunsaturated fatty acids of oil source which include about $15 \%$ saturated, $24 \%$ Monounsaturated FA and $61 \%$ polyunsaturated FA containing $53.2 \%$ linoleic acid and $7.8 \%$ linolenic acid.

Testicular cells contain high amount of PUFAs and the dominant type differs according to the species. In rat testes, the dominant one is Docosapentaenoic acid (DPA) 22:5 (n-6) (Chanmugam et al., 1991), while in human and monkey testes 
the dominant fatty acid is Docosahexaenoic acid (DHA)22:6(n3) (Nissen et al., 1978 and Connor et al., 1997).

This study was aimed to evaluate the effect of supplementation of flaxseed and soybean oils on male rats' fertility as well as to determine the antioxidant status of testicular tissues during oil supplementation.

\section{MATERIALS AND METHODS}

1-Animals: Twenty four male rats weighted about 180 to 195 $\mathrm{kg}$, divided into four groups each group contain six rats. The animals were allowed free access to water and diet. The experimental groups take a week for adaptation to laboratory conditions and the experiment continued for thirty days later.

2- Experimental design: First group, the control group $\left(G_{1}\right)$, received oil-free diet, the second group $\left(G_{2}\right)$ received diet contains flaxseed oil (high in ALA), the third group $\left(G_{3}\right)$ received diet contains soybean oil ( high in LA ) and the fourth group $\left(G_{4}\right)$ received diet contains flaxseed and soybean oils with the ratio of $75 \%: 25 \%$ respectively. All experimental diets were designed according to NCR, (1995).

3-Samples: At the end of the experiment rats were anaesthetized with diethyl ether and blood samples were centrifuged for serum collection used to hormonal analysis. Rats were dissected and epididymis was collected for obtaining semen samples used to sperm cell count and semen quality test. Testis were collected and divided longitudinally into four parts; the first part was stored into $10 \%$ formalin for histopathological examination. The second part was preserved in ice cooled phosphate buffer saline for evaluation of antioxidant activity, the third part preserved in RNA ladder for determination of $17 \beta-$ HSD3 gene expression and finally, the last part preserved in specially prepared homogenizing fluid (30 \% spectro-grade glycerol, $10 \mathrm{mmol}$ potassium phosphate and $2 \mathrm{mM}$ EDTA (100 $\mathrm{mg}$ of tissue $/ 1 \mathrm{~mL}$ homogenizing fluid) for measuring $17 \beta-H S D 3$ enzyme activity.

\section{4- Analytical methods}

\section{1-Semen evaluation}

The sperm cell count was done (Bearden and Fuquay, 1980) method. $10 \mu \mathrm{L}$ of semen samples were added to $990 \mu \mathrm{L}$ of $5 \%$ sodium bicarbonate. The number of sperm cell in 5 secondary squares of RBCs primary square was multiplied by 10,000 and the sperm cell count was estimated.. The semen quality was estimated using resazurin reduction test (Reddy and Bordekar, 1999).

\section{2-Hormonal analysis}

Testosterone hormone analysis using IMMULITE and IMMULITE 1000 Analyzer for the quantitative measurement of free testosterone in serum (Abraham, 1977). FSH was determined (Baloch et al., 2003) while LH concentration was determined (Martinon and Gergaud, 2007).

4.3- Evaluation of antioxidant activity: GSH concentration was determined by colorimetric method (Beutler et al., 1963). MDA level was determined (Satoh, 1978). NO level were estimated by Greiss reagent and helped as indicator of NO (Montgomery and Dymock,1961). GST activity was measured colorimetrically (Sheehan et al., 2001).

4.4-17- $\beta$ HSD 3 enzymatic activity: According to the method of Jarabak et al., (1962), testicular tissues were homogenized in homogenizing buffer (30\% spectro-grade glycerol, $10 \mathrm{mmol}$ potassium phosphate and $2 \mathrm{mM}$ EDTA (100 mg of tissue $/ 1 \mathrm{~mL}$ homogenizing fluid), then samples were centrifuged at $10,000 x g$ for 30 minutes. $200 \mu \mathrm{l}$ of the supernatant was taken and mixed with $440 \mu \mathrm{mol}$ sodium-pyrophosphate buffer $(\mathrm{pH}$ 10.2), $25 \mathrm{mg}$ crystalline-bovine albumin and $0.3 \mu \mathrm{mol}$ testosterone. Enzyme activity was measured after the addition of $\operatorname{NADP}^{+}(1.1 \mu \mathrm{mol})$ at $340 \mathrm{~nm}$ spectrophotometer. One unit of enzyme activity is equal to $0.001 / \mathrm{min}$ change in absorbance at $340 \mathrm{~nm}$.

4.5-Gene expression analysis of 17-6HSD3: Quantitative reverse transcriptase (qRT-PCR) PCR was done to determine the 17- $\beta$ HS3 gene expression. The extraction and purification of total RNA was done according to the instruction of RNeasy mini kit (Qiagen, Cat. No.74104) RNA concentration and quality was checked with Quawell, nanodrop spectrophotometer (USA). An equivalent of $1 \mu \mathrm{g}$ of RNA was transferred into cDNA (Thermo Fisher, Cat. No. EP0441), where $10 \mu \mathrm{m}$ of forward and reverse primers were mixed with $10 \mu \mathrm{l}$ of sybr green master mix (Intron, South korea, Cat. No. 204141).

The Reverse transcription was done at $50 \mathrm{oC} / 30 \mathrm{~min}$. After that, the amplification was done and included 40 cycles with primary denaturation at $94 \mathrm{oC} / 15 \mathrm{~min}$, secondary denaturation at $94 \mathrm{oC} / 15 \mathrm{sec}$, annealing at $60 \mathrm{oC} / 30 \mathrm{sec}$ for $\beta$ actin and at $55 \mathrm{oC} / 30 \mathrm{sec}$ for $17 \mathrm{BHSD3}$, extension at annealing at $72 \mathrm{oC} / 30 \mathrm{sec}$.

\section{6- Histopathological Examination}

Tissue was properly fixed then rinsed with phosphate buffer saline $\mathrm{pH}$ 7.4, dehydrated in alcohols with ascendinggrades, cleared using xylene finally embedded in paraffin. The blocks of paraffin were divided into $5 \mu \mathrm{m}$ thickness- sections and stained with H\&E stain. About 45-55 sections of seminiferous tubules from each group were evaluated by Johnsen score for their modified spermatogenesis index (Johnsen, 1970).

\section{RESULTS}

1-Effect of PUFAs on sperm count and semen quality: The results showed an increase in sperm cell count and improvement in semen quality in all oil supplemented groups. 
$G_{3}$ and $G_{2}$ were slightly higher than $G_{4}$ in sperm count and semen quality. $G_{3}$ was slightly higher than $G 2$ in semen quality and all groups were higher than $G_{1}$ in sperm count and semen quality table (2).

2-Effect of PUFAs on reproductive hormones: Results of hormonal analysis table (3) showed that, all oil groups have significant increase in FSH level. $G_{2}$ and $G_{3}$ increased testosterone level while there were no significant differences between all groups in LH level.

3-Effect of PUFAs on antioxidant activity in rat testis: The results of our study table (4) showed that, PUFAs improved the antioxidant activity. $G_{3}$ was the lowest group in MDA level followed by $G_{2}$ and $G_{4}$ while $G_{4}$ was the highest group in $G S H$ and GST levels. There were no significant differences between $\mathrm{G}_{1}, \mathrm{G}_{2}$ and $\mathrm{G}_{3}$ in $\mathrm{GST}$ level while $\mathrm{G}_{2}$ and $\mathrm{G}_{3}$ were higher than $\mathrm{G}_{1}$ in GSH level. There was no significant difference between all four groups in NO level.

4-Effect of PUFAs on gene expression and enzyme activity of 17 6-HSD3: The results of this study table (5) showed that, all oil groups significantly increased $17 \beta H S D 3$ gene expression and enzyme activity. $G_{3}$ was the highest group in gene expression and enzyme activity followed by $G_{2}$ and $G_{4} G_{4}$ was higher than $G_{2}$ in enzyme activity and gene expression.

5-Histopathological Finding: The obtained data revealed that, oils supplemented groups showed full order spermatogenesis and more late spermatid especially $G_{2}$ photo $(3,4)$ making oil groups between 9,10 modified Jahnsen score. The control group showed premature sloughing making the control group at modified Jahnsen score 8 photo $(1,2)$.

Table 1. designated primers.

\begin{tabular}{|c|c|c|}
\hline $\begin{array}{r}\text { Name of } \\
\text { Genes }\end{array}$ & Sequences of Primers $\left(5^{\prime}-3^{\prime}\right)$ & $\begin{array}{r}\text { References } \\
\text { and accession } \\
\text { number }\end{array}$ \\
\hline Rat $\beta$-actin & $\begin{array}{l}\text { TCCTCCTGAGCGCAAGTACTCT } \\
\text { GCTCAGTAACAGTCCGCCTAGAA }\end{array}$ & $\begin{array}{l}\text { Banni et al., } \\
2010\end{array}$ \\
\hline 17B.HSD3 & $\begin{array}{l}\text { CAACCTGCTCCCAAGTCATTT } \\
\text { TGTGTTTGAGAACAAGCTGTGTC }\end{array}$ & $\begin{array}{l}\text { Genbank } \\
\text { accession n: } \\
\text { NM_054007 }\end{array}$ \\
\hline
\end{tabular}

Table 2. Effect of PUFAs on sperm count and semen quality $(M \pm S E)$ :

$\begin{array}{lll}\text { Groups } & \text { Sperm count }\left(\mathbf{1 0}^{6} / \mathrm{ml}\right) & \text { Semen quality(RRT ratio) } \\ \mathrm{G}_{1} & 1593.33 \pm 533.33^{\mathrm{b}} & 3.21 \pm 0.38^{\mathrm{c}} \\ \mathrm{G}_{2} & 4166.66 \pm 600.92^{\mathrm{a}} & 4.74 \pm 0.34^{\mathrm{ab}} \\ \mathrm{G}_{3} & 3500 \pm 288.57^{\mathrm{a}} & 5.52 \pm 0.28^{\mathrm{a}} \\ \mathrm{G}_{4} & 2823.33 \pm 95.27^{\mathrm{ab}} & 3.91 \pm 0.37^{\mathrm{bc}}\end{array}$

Table 3. Effect of PUFAs on reproductive hormones $(M \pm S E)$ :

$\begin{array}{llll}\text { Groups } & \begin{array}{l}\text { Testosterone } \\ \text { hormone }(\mathrm{Pg} / \mathrm{ml})\end{array} & \begin{array}{l}\text { Luteinizing } \\ \text { hormone } \\ (\mathrm{mlu} / \mathrm{ml})\end{array} & \begin{array}{l}\text { Follicle stimulating } \\ \text { hormone }(\mathrm{mlu} / \mathrm{ml})\end{array} \\ \mathrm{G}_{1} & 7.32 \pm 0.27^{\mathrm{ab}} & 0.74 \pm 0.03^{\mathrm{a}} & 0.75 \pm 0.02^{\mathrm{b}} \\ \mathrm{G}_{2} & 8.04 \pm 0.39^{\mathrm{a}} & 0.79 \pm 0.03^{\mathrm{a}} & 0.85 \pm 0.02^{\mathrm{a}} \\ \mathrm{G}_{3} & 8.76 \pm 0.23^{\mathrm{a}} & 0.85 \pm 0.04^{\mathrm{a}} & 0.92 \pm 0.03^{\mathrm{a}} \\ \mathrm{G}_{4} & 6.82 \pm 0.15^{\mathrm{b}} & 0.66 \pm 0.04^{\mathrm{a}} & 0.88 \pm 0.02^{\mathrm{a}}\end{array}$

Means with different letters in the same column are significantly differed at $(p \leq 0.05)$.

Table 4. Effect of PUFAs on antioxidant activity $(M \pm S E)$ :

\begin{tabular}{|c|c|c|c|c|}
\hline Groups & $\begin{array}{l}\text { Malondialdehde } \\
\text { level (n mol/g) }\end{array}$ & $\begin{array}{l}\text { Nitric } \\
\text { oxide } \\
\text { level } \\
\text { ( } \mu \mathrm{mol} / \mathrm{L} \text { ) }\end{array}$ & $\begin{array}{l}\text { Reduced } \\
\text { glutathione } \\
\text { (mg/g.tissue) }\end{array}$ & $\begin{array}{l}\text { Glutathione- } \\
\text { S- } \\
\text { Transferase } \\
(\mu g /)\end{array}$ \\
\hline $\mathrm{G}_{1}$ & $32.07 \pm 0.8^{\mathrm{a}}$ & $1.46 \pm .04^{\mathrm{a}}$ & $2.59 \pm 0.13^{c}$ & $143.40 \pm 7.59^{b}$ \\
\hline $\mathrm{G}_{2}$ & $28.59 \pm 0.47^{b}$ & $1.46 \pm .04^{\mathrm{a}}$ & $3.02 \pm 0.04^{b}$ & $143.40 \pm 7.59^{b}$ \\
\hline $\mathrm{G}_{3}$ & $25.71 \pm 0.39^{c}$ & $1.64 \pm .11^{\mathrm{a}}$ & $2.89 \pm 0.04^{b}$ & $143.37 \pm 7.10^{b}$ \\
\hline $\mathrm{G}_{4}$ & $28.97 \pm 0.51^{b}$ & $1.68+.07^{\mathrm{a}}$ & $3.46 \pm 0.10^{\mathrm{a}}$ & $168.47 \pm 3.56^{\mathrm{a}}$ \\
\hline
\end{tabular}

Means with different letters in the same column are significantly differed at $(p \leq 0.05)$.

Table 5. Effect of PUFAs on $17 \beta$ HSD3 gene expression and enzyme activity $(\mathrm{M} \pm \mathrm{SE})$ :

$\begin{array}{lll}\text { Groups } & \begin{array}{l}\text { Real time }-P C R \text { for } \\ 17 \beta H S D 3 \text { gene } \\ \text { expression }\end{array} & \begin{array}{l}\text { Enzymatic activity of } 17 \beta \text { HSD3 } \\ \text { enzyme (unit/mg tissue/min) }\end{array} \\ \mathrm{G}_{1} & 1.00 \pm 0.057^{\mathrm{d}} & 0.0367 \pm 0.003^{\mathrm{c}} \\ \mathrm{G}_{2} & 3.69 \pm 288.57^{\mathrm{c}} & 0.0567 \pm 0.003^{\mathrm{b}} \\ \mathrm{G}_{3} & 6.75 \pm 0.24^{\mathrm{a}} & 0.0767 \pm 0.003^{\mathrm{a}} \\ \mathrm{G}_{4} & 5.41 \pm 0.14^{\mathrm{b}} & 0.0667 \pm 0.003^{\mathrm{ab}}\end{array}$

Means with different letters in the same column are significantly differed at $(p \leq 0.05)$.

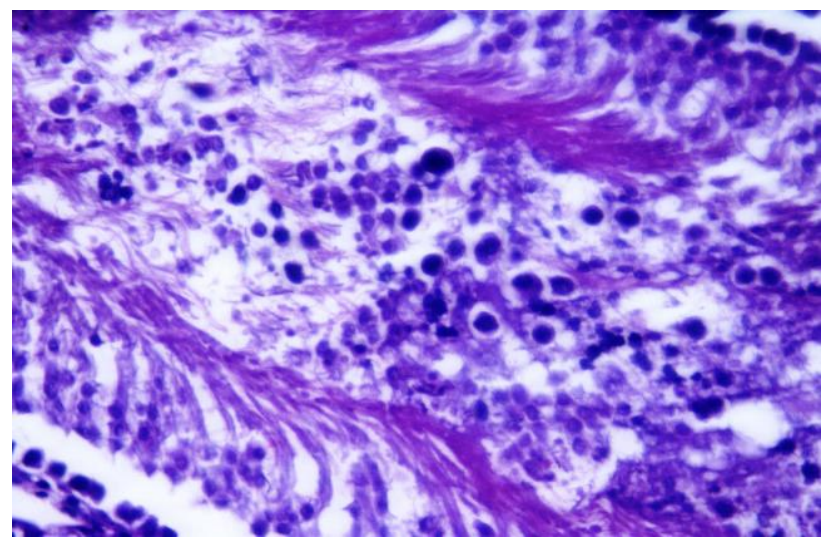

Figure 1. Control group shows late spermatids with premature sloughing modified Johnsen score 8 (high power 400x). 


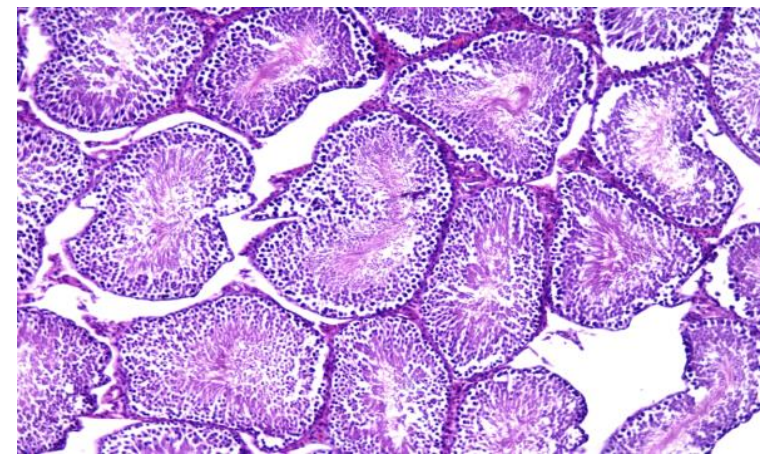

Figure 2. The control group shows late spermatids with premature sloughing making the lumen narrow (low power 100x).

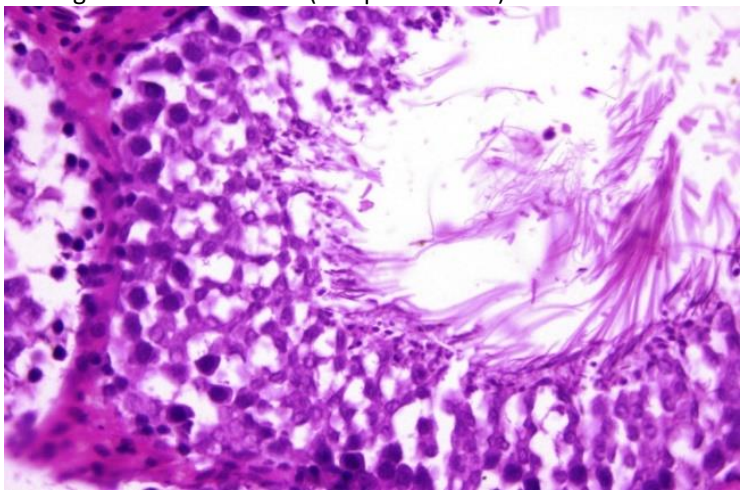

Figure 3. Flaxseed oil group shows order maturation with full spermatogenesis and many late spermatids modified Johnsen score 10 (high power 400x).

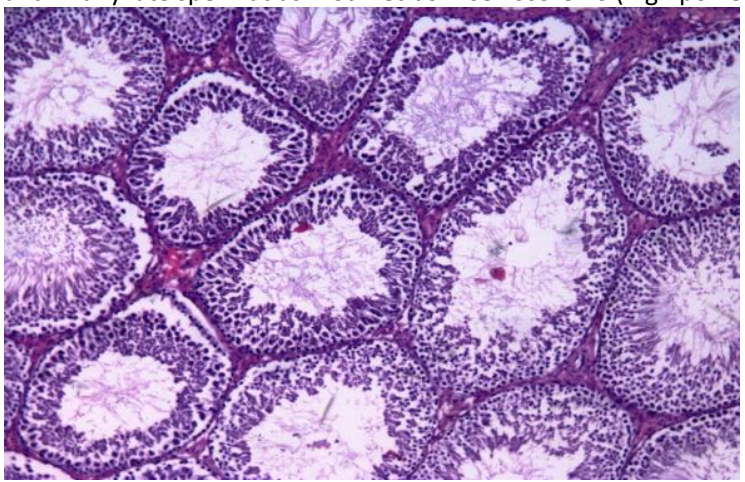

Figure 4. Flaxseed oil group show order maturation with full spermatogenesis and many late spermatids (low power 100x).

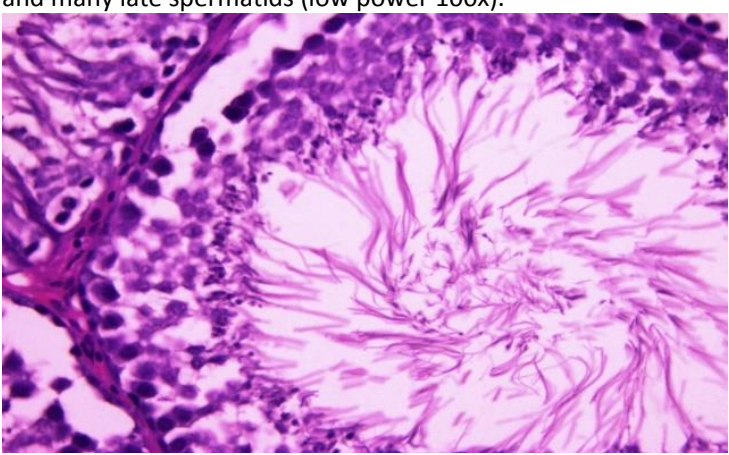

Figure 5. Soybean oil group shows spermatogenesis with frequent late spermatids modified Johnsen score 9 (high power 400x).

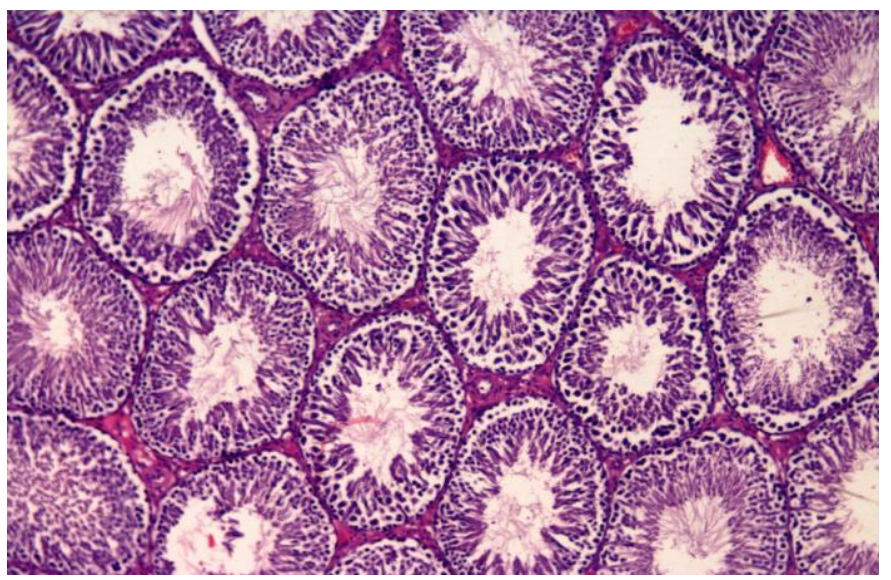

Figure 6. Soybean oil group shows spermatogenesis with frequent late spermatids (low power 100x).

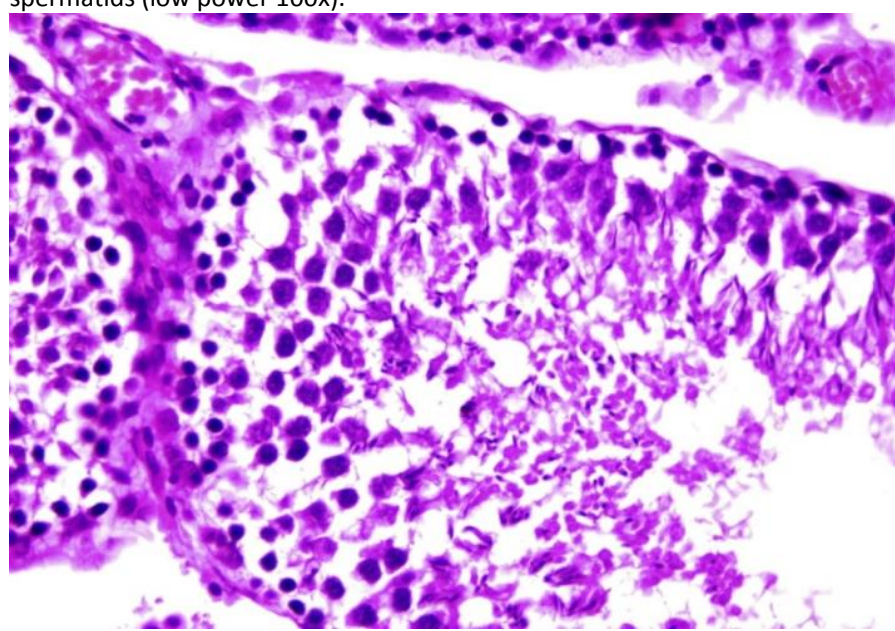

Figure 7. The group supplemented with both flaxseed and soybean oils shows spermatogenesis, primary spermatocytes and late spermatids modified Johnsen score 9 (high power 400x).

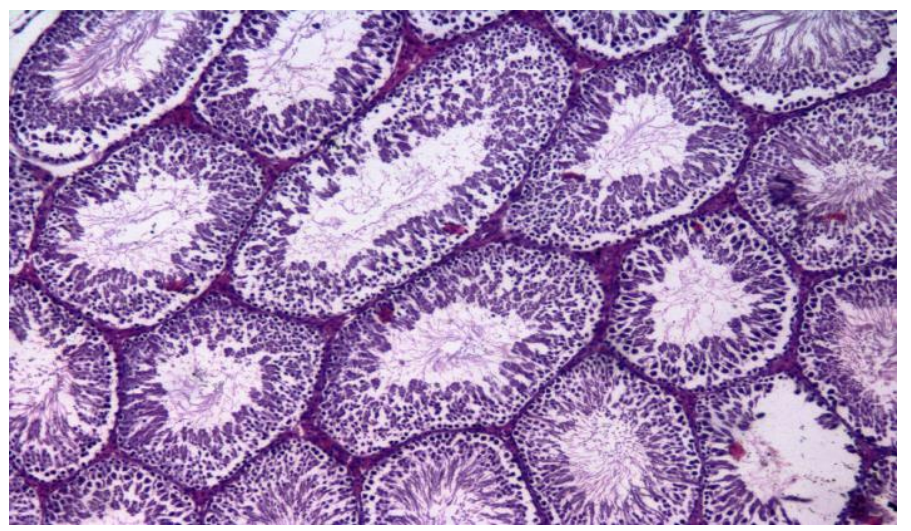

Figure 8. The group supplemented with both flaxseed and soybean oil shows spermatogenesis, primary spermatocytes and many late spermatids (low power 100x)

\section{DISCUSSION}

1- Evaluation of semen quality and sperm count: Many studies suggested that changes in the metabolism of lipids have 
effects on semen quality and fertility (Bobjer et al., 2012 and Hagiuda et al., 2014). Leat et al., (1983) found that rats feeding diet deficient in all EFAs resulted in a decrease in the concentration of sperm in the epididymis of male rats. Cells of testis and sperm have high proportion of long chains omega -3 and omega -6 ( C-20 \& C-22). Different species differ in their testicular composition of PUFAs (Saether et al., 2007). Cerolini et al., (2006) reported that, diet rich in both omega -3 and omega -6 affects the production of semen. So, omega- 3 and omega-6 PUFAs are important for reproduction and fertility. In rats, DPA 22: $5(n-6)$ is predominant in the testis and in developing rat, there is a close relation between its increase and the appearance of spermatids and spermatozoa (Davis et al., 1966 ). In man and other species like ram and bull have the long-chain metabolites of ALA 18: $3(n-3)$ are major components of the testis and spermatozoa (Bieri and Prival, 1965; Neill and Masters, 1972; Evans and Setchell, 1979). In mouse and guinea-pig, metabolites of both series of essential fatty acids are present in testis (Bieri and Prival, 1965).

The results of our study table (2) is in agreement with those of other studies used different oils contain different ratio of PUFAs. The sperm cells count, motility of sperms and grade activity increase significantly in groups treated with corn oil which contains about $58 \%$ linoleic acid and $1 \%$ linolenic acid than the control group (Saad, 2013). The status of antioxidant in sperm is supported by corn oil resulting in improvement of viability of sperm (Khatibjoo et al., 2011).

Recent studies are concerned with the ideal omega -3: omega -6 proportion in different species. Estienne et al., (2008) reported increasing in the ratio of $n-3 / n-6$ PUFAs resulted in elevation of spermatozoa quality ratio, sperm concentration and motility. Moreover, sperm deformity tended to lower while there were no effects on the testis index. Furthermore, the proportion of omega-3: omega- 6 in boar sperm were positively associated with the viability, motility, normal morphology of sperms and normal plasma cell membranes (Amin et al., 2011). High amount of omega -3 PUFA reduced the sperm cells concentration and motility which point out the value of the $n-6: n-3$ ratio in the quality of sperm (Al-Daraji et al., 2010).

2-Hormonal analysis: Feeding rabbits with omega-3, flaxseed oil $1 \%$ or flaxseed oil $2 \%$ lead to increase in levels of $\mathrm{FSH}, \mathrm{LH}$ and testosterone hormones improving steroidogenesis and spermatogenesis in rabbits (Abu-Heakal, Nabil et al., 2016). Hanis et al., (1990), found that dietary fats have significant effects on systemic turnover of androgens, not only the type of dietary fats but also the dietary fat quantity and constitution as well as the feeding period significantly affect androgen secretion and metabolism (Gromadzka- Ostrowska et al., 2002 and Gromadzka-Ostrowska, 2006).

Omega -3 PUFAs have ability to control Star and P450scc expression, enhance the production of testosterone and adjusting the reproductive process (Li et al., 2013). Not only omega -3 PUFAs that have stimulatory effects on testosterone production, but also omega- 6 PUFAs can influence androgen production (Kobayashi et al., 2013). Arachidonic acid 20:4 (n6) can increase adenyl- cyclase, thereby improving the rate of side chain cleavage of cholesterol and inducing testosterone biosynthesis. So, these FAs induce the production of testosterone.

Oil of nigella sativa consists of 50\% LA (Cheikh-Rouhou et al., 2007) and when this oil was administrated to normal and hyperlipidemic rats. The testosterone level was elevated significantly. Fish oil increases the synthesis of testosterone in testes of rats (Sebokova et al., 1990). Feeding rats corn oil rich in omega-6 PUFAs (Yong et al., 2007) increase the serum concentrations of testosterone, FSH and LH and this may be due to increase in leydig cells number, repair of leydig cells composition or both ( Saad, 2013).

Results of this experiment table (3) showed that all oil groups have significant increase in $\mathrm{FSH}$ and testosterone levels with no significant differences in LH levels. So , the elevation of testosterone level in our study maybe due to alteration in lipid constitution of the testicular membrane which may influence the binding of $\mathrm{LH}$ to its receptor leading to stimulation of the adenyl /cyclase (Sebokova et al., 1990) and testicular steroidogenic enzyme activities (Meikle et al., 1989). 3-Antioxidant status: Reactive oxygen species (ROS) induce lipid peroxidation leading to changes in sperm morphology (Sanchez et al., 2006). Moreover, oxidative stress has a harmful effect on plasma membrane of sperm which may lead to defect in the function of sperm (Iwasaki and Gagnon, 1992). ROS caused DNA damage may lead to acceleration in the apoptosis of germ cell (Agarwal et al., 2003) resulting in a decrease in sperm cells count. So PUFAs rich oil improves antioxidant activity and decreased the oxidative stress.

The result of our study table (4) showed, flaxseed and soybean oils improve antioxidant activity. Consumption of flaxseed oil significantly reduced the level of the lipid peroxidation marker (MDA). Moreover, flaxseed oil increases the serum concentrations of HDL and GSH levels (Elimam and Ramadan, 2018).

Doaa Ibrahim et al., (2018) noticed that, the diet enriched with n-3 PUFA from fish oil and linseed oil decreases serum cholesterol, triglycerides and VLDLs levels and enhances antioxidative status. Incorporation of PUFAs in cell membrane may reduce the susceptibility of cells to lipid peroxidation, change the fluidity of cell membrane, elevate enzymes activity, enhance receptor function and influence the production of lipid mediator (Best et al., 2003). This may be associated with the reaction between free radical and $(=\mathrm{CH} 2)$ in PUFAs result in avoiding free radical conjugating with fatty acids of the membrane ( Wu et al., 1998 and Alan et al., 2011). Diet rich with omega-3 can raise the concentrations of SOD, GST and GPx (Chen et al., 2012). Bhattacharya et al., (2003) GSPx activity could be increased by administration of PUFAs. 
Synthesis of GSH is up-regulated by arachidonic acid and conjugated linoleic acids mainly through stimulation of $\gamma$ glutyamylcysteine ligase (Khelifa Arab et al., 2006) and this stimulation is a feature of an antioxidant response (Lee et al., 2003).

Tjalkens et al., (1999) 4-hydroxy-2-nonenal (HNE) a product from $\omega-6$ oxidation of PUFAs can stimulate antioxidant response element result in stimulation of isozymes of GST class A including GSTA1 and GSTA4 in hepatoma cells of rat. 4Hydroxy-2(H)-nonenal (HHE) a product from $\omega$-3 PUFAs peroxidation can upregulate nuclear factor (erythroid 2-like 2) which is an important regulator of antioxidant responses in high fat-fed mice heart. Both HHE and HNE have harmful and beneficial effects and this bi-directional effects are concentration dependent (Anderson et al., 2012).

4- 17 6HSD3 gene expression and enzyme activity: The result of this study table (5) showed that, all oil groups significantly increase $17 \beta \mathrm{HSD} 3$ gene expression and enzyme activity. This result is in agreement with those of Tavakoli Darestani, (2005) who reported that both omega -3 and omega -6 affect reproduction through various mechanisms through prostaglandins precursors, they control the expression of enzymes and participate in steroids metabolism.

Also the obtained results agree with those of Wang et al.,(2018) who observed that there were a significant increase in testicular mRNA and protein levels of LH receptor, STAR, P450 scc enzyme and levels of mRNA of 33HSD , 17ßHSD and $\mathrm{Sf}-1$ in mice treated with Fish oil supplementation when compared to HFD group.

Wang et al.,(2018) Suggested that, fish oil group showed an increased in Leydig cells total number and reduction in the number of apoptotic cells resulting in stimulation of gene expression of enzymes involved in testosterone biosynthesis through the adenyl / cyclase-cyclic AMP-protein kinase A \& Splicing Factor- 1 pathways.

$17 \beta$-HSD 3 with NADP as a cofactor required for testosterone formation from androstendione in mammal testis (Labrie et al., 1997). In rodents, changes in cell membrane changes in its lipid composition could influence the binding of LH-cell membrane receptors as well as adenyl/cyclase stimulation (Sebokova, 1990) and also affect steroidogenic enzyme activities in the testes (Meikle et al., 1989). 17ß-HSD activity is stimulated by unsaturated fatty acids which is the very effective enzyme in the testosterone biosynthetic process. Also, Feeding period and the dietary fat types have significant influences on $17 \beta-$ HSD activity in rat testicular tissue (Gromadzka-Ostrowska et al., 2002). In contrast to Mark et al., (2007) found that the activity of 17ßHSD enzyme was decreased when rat groups supplemented with soybean oil, Fish oil, DHA and lard but they didn't influence testosterone levels.

5-Histopathological examination: The result of our research is in agreement with those of Abu-Heakal, Nabil et al., (2016) who found that feeding rabbits linseed oil by $2 \%$ improve most male fertile parameters including histopathological evaluation and the highest percentage of bucks in these groups had modified johnsen score 10. Also, the highest lumen diameter was in $2 \%$ linseed oil group and the group supplemented with omega-3 fatty acid.

Ayala et al., (1977) has reported that LC-PUFAs have positive effect on testicular structure including seminiferous tubules development and spermatogenesis in agreement with those of Strzezek et al., (2004) who found that omega-3 administrated boars had well developed seminiferous tubules and well developed spermatogonia cells.

Conclusion : We could be concluded that polyunsaturated fatty acids presented in soybean oil and flaxseed oil have the ability to improve fertility of male rats through enhancing spermatogenesis, steroidogenesis, antioxidant status and testicularl tissues of male rats.

\section{REFERENCES}

Abraham, G.E; Manlimos, F.S. and Garza, R. (1977): Radioimmunioassay of steroids in: Abraham GE (ed) Handbook of Radioimmunioassay. Dekker, NewYork ,PP 591-656.

Abu-Heakal, Nabil; Elseady, Youssef; El, Adel; Awadin, Walaa and Hashem, Nada. (2016): Impact of omega3 and linseed oil on male fertility in rabbits.

Agarwal , S; R. A. Saleh and M. A. Bedaiway, (2003): Role of reactive oxygen species in the pathology of human reproductive . Fertile. Steril, 79:829843

Aktas, C; Kanter, M; Erboga, M. and Ozturk, S. (2012): Anti-apoptotic effects of curcumin on cadmium-induced apoptosis in rat testes. Toxicollnd Health 28(2):122-130.

Alan, A; Hennessy, R; Paul, R; Rosaleen, D. and Catherine, S. (2011): The Health Promoting Properties of the Conjugated Isomers of $\alpha$-Linolenic Acid. Lipids. 2011;46:105-119. doi: 10.1007/s11745-010-3501-5.

Al-Daraji, H. J; Al-Mashadani, H. A; Al-Hayani, W. K; Al-Hassani, A. S. and Mirza, H. A. (2010): Effect of N-3and N-6 Fatty Acid Supplemented Diets on Semen Quality in Japanese Quail (CoturnixCoturnix Japonica), IntJ PoultSci9, 656-663.

Amin, N; Kirkwood, R. N; Techakumphu, M. and Tantasuparuk, W. (2011): Lipid Profiles of Sperm and SeminalPlasma from Boars Having Normal or Low Sperm Motility, Theriogenology75, 897-903.

Anderson, E. J; Thayne, K; Harris, M; Carraway, K. and Shaikh, S. R. (2012): Aldehyde stress and up-regulation of Nrf2-mediated antioxidant systems accompany functional adaptations in cardiac mitochondria from mice fed n-3 polyunsaturated fatty acids. Biochem J. 2012; 441(1): 359-366. doi: 10.1042/BJ20110626.

Andersson, S; Geissler, W. M; Wu, L ; Davis, D. L; Grumbach, M. M; New, M. I; Schwarz, H. P; Blethen, S. L; Mendonca, B. B; Bloise, W; et al., (1996): Molecular genetics and pathophysiology of 17beta-hydroxysteroid dehydrogenase 3 deficiency. J. Clin. Endocr.Metab.1996, 81, 130-136.

Ayala, S; Brenner, R. R. and Dumm, C. G. (1977): Effect of polyunsaturated fatty acids of the a-linolenic series on the development of rat testicular 12(3):1017-1024.

Baloch, M. Z; B.A. Ansari and N. Memon, (2003): Performance and selection of intraspecific hybrids of spring wheat (Triticumaestivum L.). Pak. J. Agric., Agril. Engg., Vet. Sci., 19(1): 28-31.

Banni, M; Messaoudi, I; Said, L; El Heni, J; Kerkeni, A. and Said, K. (2010): Metallothionein Gene Expression in Liver of Rats Exposed to Cadmium and Supplemented with Zinc and Selenium. Arch Environ ContamToxicol,59:513-519.

Bearden, H. and Fuquay, J. W. (1980): Applied animal reproduction. H. Bearden and J.W. Fuquay eds. Reston Publishing Company, Inc. A prentice Hall company, Reston, Virginia,USA.286-290. 
Best, C. A; Cluette-Brown, J. E; Teruya, M; Teruya, A. and Laposata, M. (2003): Red blood cell fatty acid ethyl esters: a significant component of fatty acid ethyl esters in the blood.J Lipid Res. 2003;44:612-620. doi: 10.1194/jlr.M200398-JLR200.

Beutler, E; Duron, O. and Kelly, B. M. (1963): Improved method for the determination of blood glutathione, J Lab Clin Med. 1963 May;61:882-8.

Bhattacharya, R. A; Lawrence, A; Krishnan, K; Zaman, D. and Sun, G. F. (2003): Effect of dietary $n-3$ and $n-6$ oils with and without food restriction on activity of antioxidant enzymes and lipid peroxidation in livers of cyclophosphamide treated autoimmune-prone NZB/W female mice J Am CollNutr, 22 (2003), pp. 388-399.

Bieri, J. G. and Prival, E. L. (1965): Lipid composition of testes from various species. Comparative Biochemistry and Physiology 15, 275-282.

Bobjer, J; Naumovska, M; Giwercman, Y. L. and Giwercman, A. (2012): High prevalence of androgen deficiency and abnormal lipid profile in infertile men with non-obstructive azoospermia. Int J Androl 35,688-694.

Cerolini, S; Zaniboni, L; Maldjian, A. and Gliozzi, T. (2006): Effect of Docosahexaenoic Acid and $\alpha$-Tocopherol Enrichment in Chicken Sperm on Semen Quality, Sperm Lipid Composition and Susceptibility to Peroxidation, Theriogenology 66, 877-886.

Chanmugan, P. S; Boudreau, M. D. and Hwang, D. H. (1991): Dietary (n-3) fatty acids alter fatty acid composition and prostaglandin synthesis in rat testis. J Nutr 121:1173-8.

Cheikh-Rouhou, S; S.Besbes; B. Hentati; C. Blecker; C. Deroanne and H. Attia, (2007): Nigella sativa L. Chemical composition and physiochemical characteristics of lipid fraction. Food chem ., 101 :673-681.

Chen, W; Wang, J.P. and Huang, Y.Q. (2012): Effect of dietary n-6: n-3 polyunsaturated fatty acid ratio on cardiac antioxidative status, T-cell and cytokine mRNA expression in the thymus, and blood T lymphocyte subsets of broilers LivestSci, 150 (2012), pp. 114-120.

Connor, W. E; Lin, D. S. and Neuringer, M. (1997): Biochemical markers for puberty in the monkey testis :desmosterol and docosahexaenoic acid. J Clin Endocrinal Metab 82:1911-6.

Davis, J. T; Bridges, R. B. and Coniglio, J. G. (1966): Changes in lipid composition of the maturingrat testis. Biochemical Journal 98, 342-346.

Doaa Ibrahim; Rania El-Sayed; Safaa I. Khater; Enas N. Said and Shefaa A.M. El Mandrawy, (2018): Changing dietary $n-6: n-3$ ratio using different oil sources affects performance, behavior, cytokines mRNA expression and meat fatty acid profi le of broiler chickens, Animal Nutrition 4 (2018) $44 \mathrm{e} 51$.

Elimam, H. and Ramadan, B. K. (2018): Comparative Study of the Possible Prophylactic and Curative Effects of Flaxseed Oil on the Lipid Profile and Antioxidant Status of Hyperlipidaemic Rats. J Appl Pharm 10: 257. doi: 10.4172/1920-4159.1000257.

Esmaeili, V; Shahverdi, A. H; Alizadeh, A. R; Alipour, H. and Chehrazi, M. (2014): Saturated, omega-6 and omega-3 dietary fatty acid effects on the characteristics of fresh, frozen-thawed semen and blood parameters in rams. Andrologia 46, 42-49.

Estienne, M. J; Harper, A. F. and Crawford, R. J. (2008): Dietary Supplementation with a Source of Omega-3 FattyAcids Increases Sperm Number and the Duration of Ejaculation in Boars, Theriogenology70,7076.

Evans, R. W. and Setchell, B. P. (1979): Lipid changes during epididymal maturation in ramspermatozoa collected at different times of the year. Journal ofReproduction and Fertility 57,197-203.

Gagnon , C; A. Iwasaki; De, E. Lamirande and N. Kovalski, (1991): Reactive oxygen species and human spermatozoa .Ann. N.Y. Acad . Sci.,637:409416.

Ge, R.S. and Hardy, M.P. (1998): Variation in the endproducts of androgen biosynthesis and metabolismduring postnatal differentiation of rat Leydig cells. Endocrinology 1998, 139, 3787-3795.

Gromadzka- Ostrowska, J; Przepiorka, M. and Romanowicz, K. (2002): Influence of dietary fatty acids composition, level of dietary fat andfeeding period on some parameters of androgen metabolism in malerats. Reprod. Biol. 2, 277-293.

Gromadzka-Ostrowska, J. (2006): Effects of dietary fat on androgen secretion and metabolism 10 July 2006 Department of Dietetics, Faculty of Human
Nutrition and Consumer Sciences, Warsaw Agricultural University, Poland.

Hagiuda, J; Ishikawa, H; Furuuchi, T; Hanawa, Y and Marumo, K. (2014): Relationship between dyslipidaemia and semen quality and serum sexhormone levels: an infertility study of 167 Japanese patients.Andrologia 46, 131-135.

Hanis, T; Zidek, V; Sachova, J; Klir, P and Deyl, Z. (1990): Effects of dietary trans-fatty acids on reproductive performance of Wistar rats. British Journal of Nutrition 61 519-29.

Iwasaki, A. and C. Gagnon, (1992): Formation of reactive oxygen species in spermatozoa of infertile patients. Fertile, Steril.,57:409-416.

Jarabak, J; Adams, J. A; Williams-Ashman, H. G. and Talalay, P. (1962): Purification of 17 beta-hydroxysteroid dehydrogenase of humanplacenta and studies on its transhydrogenase function. J BiolChem 237:345-357.

Jedlinska-Krakowska, M; Bomba, G; Jakubowski, K; Rotkiewicz, T; Jana, B. and Penkowski, A. (2006): Impact of oxidative stress and supplementation with vitamins $\mathrm{E}$ and $\mathrm{C}$ on testes morphology in rats. J. Reprod. Dev., 52: 203-209.

Johnsen, S. G. (1970): Testicular biopsy score count--a method for registration of spermatogenesis in human testes: normal values and results in 335 hypogonadal males. Hormones. 1970; 1(1):2 25.

Khatibjoo, A; Kermanshahi, H; Alimon, R; Golian, A. and Zaghari, M. (2011): Effect of Omega 6: Omega3 Fatty Acid Ratios on Semen Quality of Malaysian Village Roosters", Global Veterinaria6 (2), 213-219.

Khelifa Arab; Adrien Rossary; Laurent Soule're and Jean-Paul Steghens, (2006): Conjugated linoleic acid, unlike other unsaturated fatty acids, strongly induces glutathione synthesis without any lipoperoxidation DOI: 10.1017 /BJN 20061910. British Journal of Nutrition (2006), 96, 811-819.

Kobayashi, M; Hori, T. and Kawakami, E. (2013): Changes in prostaglandine E2 levels in seminal plasma during ejaculation and the effect of exogenous prosta- glandine E2 on semen volume in the dog . J Vet Med Sci. 2013;75(9):1249-52.

Kochhar, P. (2002): Lipid biochemistry. An introduction (5th edition). Int J Food SciTechnol 37, 899-900.

Labrie, F; Luu-The, V; Lin, S. X; Labrie, C. and Simard, J. (1997): The key role of 17beta-hydroxys-teroid dehydrogenases in sex steroid biology. Steroids 62 148-58.

Leat, W. M; Northrop, C. A; Harrison, F. A. and Cox, R. W. (1983): Effect of dietary linoleic and linolenic acids on testicular development in the rat. $\mathrm{Q}$ J ExpPhysiol 68:221-31

Lee, J. M; Calkins, M.J; Chan, K; Kan, Y.W. and Johnson, J.A. (2003): Identification of the NF-E2-related factor-2-dependent genes conferring protection against oxidative stress in primary cortical astrocytes using oligonucleotide microarray analysis. J BiolChem 278, 12029- 12038.

Li, Y; Liu, L; Wang, B; Xiong, J; Li, Q; Wang, J and Chen, D.(2013): Impairment of reproductive function in a male rat model of non-alcoholic fatty liver disease and beneficial effect of n-3 fatty acid supplementation. Toxicol. Lett. 2013;222:224-232. Doi : 10.1016/j. toxlet .2013 . 05.644.

Mark, J. McVey; Gerard, M. Cooke; Ivan, H. A. Curran; Hing Man Chan; StanKubow; Eric Lok and Rekha Mehta, ( 2007): Effects of dietary fats and proteins on rat testicular steroidogenic enzymes and serum testosterone levels Food and Chemical Toxicology 46 :259-269.

Martinon, P. and Gergaud, J. (2007): Using switching detection and variational equations for the shooting method. Optim. Control Appl. Meth., 28: 95 116. doi:10.1002/oca.794.

Meikle, A. W; Benson, S. J; Liu, X.H; Boam, W.D. and Stringham, J. D. (1989): Nonestrified fatty acids modulatesteroidogenesis in mouse Leydig cells. American Journal of Physiology 257 E937-E942.

Montgomery, H.A.C. and Dymock, J. (1961): The determination of nitrite in water. Analyst, 86, 414-416.

Mosher, W. D. and Pratt, W. F. (1991): Fecundity and infertility in the United States: Incidence and trends. J FertilSteril., 56: 192-193.

Neill, A. R. and Masters, C. J. (1972): Metabolism of fatty acids by bovine spermatozoa. Biochemical Journal 127, 375-385.

Nissen, H.P; Heinze, I; Kreysel, H. W. and Schirren, C. (1978): Fatty acid composition of neutral lipids of human semen .Andrologia 10:390-2. 
A. H. and Youngblood, G.(1995): Regulation of expression of steroidogenic enzymes in the Leydig cells. Biol. Reprod.52,217-225.

Penning, T. M. (1997): Molecular endocrinology of hydroxysteroid dehydrogenases. Endocr. Rev. 1997,18, 281-305.

Prasad, A. S. (2013): Discovery of human zinc deficiency: its impact on human health and disease. AdvNutr 4, 176-190.

Pryor, W. A; Houk, K. N; Foote, C. S; Fukuto, J. M; Ignarro, L.J; Squadrito, G.L and Davies, K. J. A.(2006): Free radical biology and medicine: it's a gas, man! Am J PhysiolRegullntegr Comp Physiol. 2006; 291 : R491 - R511.

Reddy K.V. and Bordekar A.D. (1999): Spectrophotometric analysis of resazurin reduction test and semen quality in men. Indian J Exp Biol 1999, 37, 782-786.

Rosler, A; Silverstein, S. and Abeliovich, D.A. (1996): (R80Q) mutation in 17 beta-hydroxysteroiddehydrogenase type 3 gene among Arabs of Israel is associated with pseudohermaphroditism inmales and normal asymptomatic females. J. Clin. Endocr.Metab.1996, 81, 1827-1831.

Saad, N. (2013): The Effect of Corn Oil in Sperm Parameters and Levels of Some Hormone, Elements, and Biochemical Parameters in Serum of White Male Rabbits, Journal of Natural Sciences Research ISSN 22243186 (Paper) ISSN 2225-0921 (Online)Vol.3, No.12, 2013.

Saether, T; Tran, T.N; Rootwelt, H; Grav, H.J; Christophersen, B. O. and Haugen, T. B. (2007): Essential fatty acid deficiency induces fatty acid desaturase expression in rat epididymis, but not in testis. Reproduction 133, 467-477.

Sanchez, E. E. T; M.L. Marquette; D. B. Brown and N. H. Ansari, (2006): The effect of oxidative stress on human sperm morphology . Fertil, Steril., 86 (Suppl.1). S444. In Am. Soo. Reprod. Med. 62 nd Annual Meeting

Satoh, K. (1978): Serum lipid peroxide in cerebrovascular disorders determined by a new colorimetric method. Clinica Chimica Acta, 90, 37-43.

Sebokova, E; Garg, M. L; Wierzbicki, A; Thompson, A. B. and Clandinin, M. T. (1990): Alteration of the lipid composition of rat testicular plasma membranes by dietary ( $n-3)$ fatty acids changes the responsiveness of Leydig cells and testosterone synthesis. Journal of Nutrition 120610 618.

Sheehan, D; Meade, G. and Foley, V. M. (2001): Structure, function and evolution of glutathione transferases: implications for classification of non-mammalian members of an ancient enzyme super family. Biochem J 360(1): 1-6.

Strzezek, J; Fraser, L; Kuklinska, M; Dziekonska, A. and Lecewicz, M. (2004): Effects of dietary supplementation with polyunsaturated fatty acids . Repr., biolog .,4.3: pp271.

Tavakoli Darestani, A; Kimiagar, S. M and Velaei, N. (2005): Walnut effect on serum lipids in postmenopausal women. J. Mazandaran Uni. Med. Sci. 2005; 14(44):21-32.

Thomas, (2002): Bartram's Encyclopedia of Herbal Medicine: The Definitive Guide to the Herbal Treatments of Diseases. Da Capo Press. p. 271.ISBN 978-1-56924-550-7.

Tjalkens, R.B; Luckey, S. W; Kroll, D. J. and Petersen, D.R. (1999): Alpha, betaunsaturated aldehydes mediate inducible expression of glutathione stransferase in hepatoma cells through 393 activation of the antioxidant response element (ARE). AdvExp Med Biol. 1999; 463: 123-131.

Vujkovic, M; De Vries, J. H; Dohle, G. R; Bonsel, G.J; Lindemans, J; Macklon, N.S; Van der Spek, P. J; Steegers, E.A. and Steegers-Theunissen, R. P. M. (2009): Associations between dietary patterns and semen quality in men undergoing IVF/ICSI treatment. Hum Reprod 24, 1304-1312.

Wang, H; Cai, Y; Shao, Y; Zhang, X; Li, N; Zhang, H. and Liu, Z. (2018): Fish Oil Ameliorates High-Fat Diet Induced Male Mouse Reproductive Dysfunction via Modifying the Rhythmic Expression of Testosterone Synthesis Related GenesInt J Mol Sci. 2018 Apr 29;19(5). pii: E1325. doi: 10.3390/ijms19051325. PMID: 29710834.

Wathes, D. C; Abayasekara, D. R. E. and Aitken, R.J. (2007): Polyunsaturated fatty acids in male and female reproduction. Bio Reprod 77, 190-201.

Wu, D and Meydani, S. N. (1998): N-3 polyunsaturated fatty acids and immune function. Pro cNutr Soc. 1998;57:503-509. doi: 10.1079/PNS19980074.

Yong, Q; Isabelle, M; Younong, M; Ruping, W; Jiansheng, W; Donna, P; Mark, J; Cline, M; Thomas, T; George, K; Adrienne, S; Iris, J; Ralph, D; Hao, Z; Hong, W and Jing, X. (2007): Modulation of prostate cancer genetic risk by omega- 3 and omega- 6 fatty acids. The Journal of Clinical Investigation. 117 (7): 1866-1875. doi: 10.1172 /JCl31494. PMC 1890998. PMID 17607361.

Mans Vet Med J $20: 1$ (2019) 67-74 